\title{
Partner in Jihad: Marriage, Women and Deradicalised Terrorists in Indonesia
}

\author{
Dzuriyatun Toyibah ${ }^{*}$ \\ 1 Department Sociology, The Faculty of Social and Political Sciences, Syarif Hidayatullah State Islamic \\ University, Jakarta, Indonesia; e-mail: dzuriyatun.toyibah@uinjkt.ac.id \\ * Correspondence
}

Received: 2021-11-28; Accepted: 2021-12-15; Published: 2021-12-31

\begin{abstract}
The involvement of women in jihad has increased significantly in many countries including Indonesia. This changes the image that women are underrepresented in relation to acts of jihad and terrorism. Drawing from in depth-interviews with six wives of disengaged terrorists in 2016, the current article aims to explain their marriage and support in jihad. Applying religious radicalisation frameworks ranging from pre-radicalisation to jihadisation, the participants have not achieved the final step. They mostly believe in allowing jihad in conflict-ridden countries, but not in Indonesia. Marriage and family are very important to introduce the ideology of allowing violence in conflictridden areas. Their husband's affiliation to a radical group has the potential to support the wives to strengthen their network within the terrorist circle. However, in general, the participants were not intensively engaging in religious studies (pengajian), were limited from connecting with their past friends after their husbands were sentenced. They disagreed with their husband's dream and actions. Therefore, the potential network for continuing radicalisation will not develop very significantly.
\end{abstract}

Keywords: Income-generating; jihad; marriage; religious radicalisation; women.

\begin{abstract}
Abstrak: Keterlibatan perempuan dalam terorisme meningkat secara signifikan termasuk di Indonesia. Hal tersebut merubah anggapan bahwa perempuan tidak cukup berpartisipasi dalam jihad dan terrorism. Berdasarkan wawancara mendalam terhadap 6 istri teroris yang telah menyatakan berhenti dari aktifitas jihad pada tahun 2016, artikel ini menggambarkan pentingnya pernikahan dan dukungan mereka terhadap jihad dan radikalisasi agama. Dengan menggunakan kerangka pemikiran tahapan jihad dari pra radikal sampai jihadisasi, partisipan penelitian ini belum mencapai pada tahapan ahir. Mereka mendukung jihad dan tindakan kekerasan di negara-negara konflik tetapi menolak jihad dengan melakukan pengeboman di Indonesia. Pernikahan dan kehidupan keluarga merupakan hal sangat penting yang mengenalkan pemikiran bahwa kekerasan dalam berjihad bisa dibenarkan di daerah konflik. Afiliasai suami mereka pada organisasi radikal merupakan factor yang membuat mereka berpotensi untuk memperkuat jaringan di lingkungan kelompok terrorist. Namun, secara umum partisipan tidak terlalu aktif dalam kelompok pengajian, juga memliki hubungan yang sangat terbatas dengan kelompok teroris setelah suami mereka mendapatkan hukuman. Mereka juga tidak setuju dengan keinginan dan tidakan suami mereka. Dengan demikian, jaringan yang cukup potensial tersebut tidak akan berkembang dengan signifikan.
\end{abstract}

Kata Kunci: Jihad; pencari nafkah; perempuan; pernikahan; radikalisasi agama.

\section{Introduction}

The topic of gender, jihad, and terrorism have raised the attention of many scholars (Ispahani, 2016; Johnston et al., 2020; Phelan, 2020). In this article, jihad refers to modern jihadism, which allows violence in its execution (including bombing), and it is subsequently called terrorism by the out-group (de Leede, 2018). Early radical groups before IS/ISIS such as early Jema' ah Islamiah considered women should be excluded from the battlefield based on the ruling that women are only permitted to travel in 
the company of their husbands or a mahram (a male member of the family with whom marriage is prohibited) (Lahoud, 2014) (IPAC, 2017).

Instead of being a perpetrator of terror or a combatant, women are generally assumed to maintain active roles for peacemaking (Andrews, 2020; Aoláin, 2013; Fikriyati, 2015; Satterthwaite \& Huckerby, 2013). However, more recent findings show a changing trend that women are both victims and combatants (Bloom, 2011; Rufaedah \& Putra, 2018; Spencer, 2016). Spencer (2016) identifies various roles that women hold (with actions assigned or required) in the Islamic State of Iran and Syria (ISIS/IS), the most important transnational group of Islamic radicalism at present. Nowadays, women have been considered highly crucial actors in various terrorist activities as collaborators, informers, human shields, recruiters, and sexual bait (Berko \& Erez, 2007; Bloom, 2011; de Leede, 2018; O'Rourke, 2009). Women have the same motivation as men to revive the social norms that they believe in ( $\mathrm{O}^{\prime}$ Rourke, 2009) but according to (Agara, 2015) (Sjoberg, 2007) women perpetrators of suicide attacks in many countries are not based on individual freedom and choice. Accordingly, (Bloom \& Lokmanoglu, 2020) are questioning female agencies for terrorism because they have never acted independently, male terrorists have always been behind their actions.

Marriage and family are very important instruments for religious radicalisation (Fenton, 2014; Ismail, 2020; Osman, 2010) as well as for disengagement (Altier, Thoroughgood, \& Horgan, 2014; Hwang, 2017). It is very common for jihadist leaders to arrange marriage to recruit future jihadists. Similarly, radicalisation has occurred under the influence of parents, brothers, and extended family (Ismail, 2007; Milla, Faturochman, \& Ancok, 2013). In radical groups, wives are expected to play the role of income-generating because their husbands are focusing on jihad, and the most radical group are allowing and supporting the wives for doing amaliah (jihad) (IPAC, 2017). This social reality indicates that women are recently more capable of adopting the masculine culture. This corroborates Castell's argument (1996) on the end of patriarchy as more women are participating in male-dominated fields (Sjödin, 2004).

Literature about the involvement of women in jihad and terrorism from Indonesia is growing (Abdul Nasir, 2019; Azca and Putri, 2021; Bloom, 2011; IPAC, 2017; Muryanti, 2015). Some are about how women get involved in acts of terror and their motivation (Bloom, 2011; IPAC, 2017), the stigma for wives of perpetrators (Rufaedah \& Putra, 2018), and others are about women's involvement in counter radicalism (Fikriyati, 2015), women agency in extremism regeneration and disengagement (Azca \& Putri, 2021) and women's role in deradicalisation (Fikriyati, 2015).

Similarly, there have been numerous studies about social capital for religious radicalisation terrorism (Bélanger et al., 2020; Cox, 2009; Kaakinen et al., 2018; Shamaileh, 2017). Aly and Strienger (2012) claim that people are more likely to be radical when they are part of a radical group and that radical belief has a strong correlation with radical acts (Aly and Striegher, 2012). Family and associational membership to create a network is a very important factor for religious radicalisation and deradicalisation (Doosje et al., 2016; Silber \& Bhatt, 2007). Drawing from in depth-interviews with six wives of deradicalised convicted terrorists by applying a religious radicalisation framework, this current article aims to discuss women (wives of deradicalised terrorist), marriage, and religious radicalisation.

The research method involved in-depth interviews carried out in 2016 with 6 wives of disengaged terrorists (see Table 1). The researcher contacted them via their husbands who were joining a counter radicalism program organised by a civil society organisation. Once their husband agreed to give their wife's contact number, the researcher texted them and made an appointment to meet with them. Usually, they asked the researcher to meet in a quiet restaurant and then the interviews were conducted for roughly about 1 to 2 hours. All interviews were recorded and transcripted to serve as primary data for the research. The researcher subsequently classified the data based on the trends found in previous research findings on women's involvement in terrorism.

First participant Ami is married to a terrorist accused of being involved in a terrorist network related to the September $11^{\text {th }}$ attack in 2001 and the Bali bombing in October 2002. He was a member of Jemaah Islamiyah (JI). The second Anti is married to a vegetable seller who was sentenced to 5 years in 
prison by a court in East Jakarta in September 2012 for concealing a firearm. The third Rani is the wife of a courier and a driver that picked up and dropped off people directly involved in bombings at the JW Marriot and Ritz Carlton on July 17, 2009. He was recruited into the radical group by his relative and was sentenced to 6 years, for engaging in terrorist networks and bombings. The fourth Dita is the wife of an ex-active police officer that was involved in supplying firearms for military training to a group in Aceh in 2010. He was, thus, punished as a member of a terrorist group and sentenced to 6 years. The fifth Lita hid her husband, who was wanted by Densus 88 in a terrorism case. Her husband was sentenced to six years. The sixth participant Nana is a woman who is married to a jihadist, which assembled bombs in preparation for jihad war and was sentenced to 6 years.

The real names of the informants are not used to maintain confidentiality. None of the husbands of the participants were members of ISIS, and thus this research discusses the role of women in religious radicalisation that only pertains to non-ISIS groups. The husbands were mostly affiliated with Jama'ah Islamiyah (JI).

Table 1 Six wives of convicted terrorists

\begin{tabular}{|c|c|c|c|c|c|}
\hline & $\begin{array}{c}\text { Current } \\
\text { Age/ } \\
\text { Age at } \\
\text { Marriage }\end{array}$ & $\begin{array}{l}\text { Current Address/ } \\
\text { Hometown }\end{array}$ & Occupation & Education & $\begin{array}{l}\text { Length of } \\
\text { Sentenced }\end{array}$ \\
\hline Ami & $51 / 21$ & Depok/ Jakarta & Housewife & $\begin{array}{l}\text { Senior High } \\
\text { School }\end{array}$ & 6 year \\
\hline Anti & $50 / 19$ & Jakarta/Ngawi & Vegetable Seller & Primary School & 5 years \\
\hline Rani & $37 / 30$ & Cibubur/Kuningan & $\begin{array}{l}\text { She used to sell soy } \\
\text { milk (by dispatching } \\
\text { them in shops) and is } \\
\text { currently a housewife. }\end{array}$ & $\begin{array}{l}\text { Junior high } \\
\text { school, Pesantren }\end{array}$ & $\begin{array}{c}\text { Initially, } \\
10 \text { years } \\
\text { but it } \\
\text { reduced to } \\
6 \text { years }\end{array}$ \\
\hline Dita & $36 / 20$ & $\begin{array}{l}\text { Tangerang/ } \\
\text { Yogyakarta }\end{array}$ & $\begin{array}{l}\text { She was a shopkeeper } \\
\text { and is currently a } \\
\text { housewife. }\end{array}$ & $\begin{array}{l}\text { Vocational } \\
\text { School (SMK) }\end{array}$ & 6 years \\
\hline Lita & $33 / 25$ & Bekasi/Medan & $\begin{array}{l}\text { She was a school } \\
\text { administration staff } \\
\text { and is currently a } \\
\text { housewife }\end{array}$ & $\begin{array}{l}\text { Senior High } \\
\text { School }\end{array}$ & 6 years \\
\hline Nana & $35 / 19$ & Bandung/Bandung & $\begin{array}{l}\text { She was a } \\
\text { kindergarten teacher }\end{array}$ & $\begin{array}{l}\text { Senior High } \\
\text { School }\end{array}$ & 6 years \\
\hline
\end{tabular}

\section{Jihad and Religious Radicalisation}

The original meaning of jihad is the inner struggle against temptation, and it is also used to refer to fighting against injustice and oppression, spreading and defending Islam, and creating a just society through preaching, teaching, armed struggle, or holy war (de Leede, 2018). Jihad is one of the teachings of Islam, it is mentioned 41 times in the Holy Qur'an, it is an obligation that must be fulfilled until the day of Judgement. This is referred to in a verse in the Holy Qur'an (Q.S. al Baqarah: 216), that jihad is an obligation although it may bring unhappiness. Something you do not like may be good for you and conversely, something you like is not necessarily good for you (Putra \& Sumaryani, 2021). Jihad is not limited to war or battlefield (Ali \& Rehman, 2005; Lynch, 2010; Noor, 1985). Muslims can perform jihad at various measures such as by their action, heart, mind, and words. Interestingly, the greatest jihad according to a hadith is war and self-control against lust and upholding the truth. In the early years of Islam, jihad refers to the battlefield and war to spread monotheism, but it is stated in the Holy Qur'an 
that the People of the Book (Ahlul Kitab) such as Christians, Jews, and Sabians are subject to moderate treatment. The call for jihad referred to in this definition is not for individuals but the unjust Caliphs or Imam the head of the Muslim government.

Later, modern jihadism developed into a transnational ideology with strong anti-Western views. It shares the broad goals of safeguarding what they see as 'true' Islam and establishing its supremacy over both internal and external enemies by returning to a puritanical and literalist understanding of the faith found in Salafism (de Leede, 2018). Salafism refers to an ideology upheld by a group of Muslims striving to purify Islamic teachings, by rejecting innovation as well as pluralism and strictly implementing the Prophet Muhammad's model applied in the classical period. However, Wiktorowicz (2006) notes that Salafi, which is usually synonymous with the Wahhabi movement, has at least three interpretations regarding jihad and its association with violence. They are the purists (who believe in non-violent methods), the politicos (who consider politics as a crucial aspect for advocating social justice and legalising Islamic law), and the jihadis (who allow violence and revolution for jihad). Ever since, non-believers have associated jihad with its pejorative meaning, interchangeable with martyr, martyrdom operation, qital, amalia the last step of religious radicalisation (IPAC, 2017; Perešin, 2015; Sela-Shayovitz \& Dayan, 2021).

Religious radicalisation has been defined as the socialisation process of religious belief whereby people are led to commit acts of violence for religious reasons (Aly \& Striegher, 2012; Jones \& Dawson, 2021; Malthaner, 2014; Winter \& Muhanna-Matar, 2020). Radicalisation has many broad and specific definitions. In its broadest definition, radicalisation includes all uncommon or extreme beliefs, but most definitions classify it as the use of violence to reach a goal. Silber and Bhatt, (2007) identify four stages of radicalisation: pre-radicalisation (when individuals interact with people involved in radicalisation), self-identification (when both internal and external factors from political and social spheres such as marginalisation and discrimination lead them to adopt an extreme belief and support radical acts), indoctrination (when the extreme beliefs intensify and they are urged to engage in new radical beliefs), and jihadisation (the final step, which is the stage when these people choose to become directly involved in violent acts, to become a 'warrior') (Milla et al., 2013)

On the other hand, (Doosje et al., 2016) identify three steps of radicalisation at the micro, meso as well as macro levels. First, is the sensitivity stage when people feel negligible, disorientation of social status, indignity, and mental pain, belonging to a group of people with similar feelings and experiencing various discrimination. Globalisation has led to Western domination threatening nonWestern cultures, beliefs, and ideologies. Second, the feeling of group affiliation or being a member of a group when they join a radical group. This reinforces their in-group feeling, commitment, and loyalty toward radical belief. The third step (action using violence) is motivated by factors at all levels.

\section{Women in Jihad, Terrorism and Religious Radicalisation}

Spencer (2016) identified two roles that women play in radical groups: the domestic role and the operational role. The domestic role is very important; especially because when women play their role as wives and reproduce, they are creating the next generation. Additionally, wives support their husbands psychologically; provide with all their husbands' need in relation to food, comfort, cleanliness, and sexual satisfaction. Recently, the operational role has increased significantly. However, wives' involvement in religious radicalisation and terrorism has been varied from active to passive supporter and active and passive prevent (Azca \& Putri, 2021).

Agency related to terrorism refers to an individual ability to manage social experience and decide the strategy and solve life problems (Azca \& Putri, 2021; Sjoberg \& Gentry, 2011). Agency is defined as "the capacity for autonomous action in the face of often overwhelming cultural sanctions and structural inequalities."(Burke, 2012); or "people's capacity to make choices and take action in the world" (Rinaldo, 2014; Riyani, 2021). People exhibit agency when they act in unexpected ways, despite how actions are shaped by social institutions and internalised customs and traditions (Burke, 2012). 
Women's agency in terrorism and counter-terrorism in Indonesia has been discussed by previous literatures (Azca \& Putri, 2021; Fikriyati, 2015; IPAC, 2017). According to a report by (IPAC, 2017), Indonesian women have been involved in radicalisation since the 1980s recruited by the radical group Darul Islam (DI). Two main agendas had been the core activities of early women's radicalisation: promoting headscarf (jilbab) and flourishing group of dakwah (inviting people to Islam and to learn Islam comprehensively/kaffah) by establishing usrah groups (including in many schools and universities), and eventually stating baiat (sworn allegiance) to DI leaders. The next stage is radicalisation in Jama'ah Islamiah (JI), which is part of Salafi jihadi (allowing violence and revolution in jihad). Here, women are required to wear a longer headscarf even a face veil (niqab/chador), focus on the domestic role, take part in generating family income, and obey leaders. Women can be involved in study groups to teach other women, and be involved in JI under their husband's oath of allegiance to become loyal supporters and helpers. In the final stage, women are directly involved in IS/ISIS's jihad including bombing. Marriage in radical groups such as JI is very important because it supports the regeneration of jihad. The wife's role for regeneration among terrorists is discussed by many scholars (Abdul Nasir, 2019; Azca \& Putri, 2021; Bloom, 2011; de Leede, 2018; IPAC, 2017). Their roles for regeneration include maintaining the ideology of jihadism on the one hand and cutting the chain of jihadism on the other (Azca \& Putri, 2021). The former is still maintained to follow the father's footsteps, by contrast, the latter emphasises children's dedication to providing benefit to society. In other words, marriage and family are very important for the success of both radicalisation and deradicalisation.

We argue that women's affiliation with state-building jihadi organisations has helped to enhance their agency to actively participate in achieving the organisations' agenda. Operation-based jihadi organisations are known as Islamist terrorist groups that aim to compel a target government to change its policy and to cause democratic states to withdraw forces from the land the terrorist perceives as their national homeland (Khelghat-Doost, 2019). State-building organisations are those which have officially declared the establishment of their states (caliphates) and have set up relevant institutions with specialised objectives to administrate the societies they rule (Khelghat-Doost, 2019). By contrast, those who believe in the norms of radicalisation and terrorism but are not directly affiliated with radical organisations and networks have a greater potential of leaving radicalisation behind as well as cutting the chain of radicalisation in their family both passively or actively of prevention.

\section{Women's Roles and Supports in Religious Radicalisation}

The six interviewed wives chose domestic roles as their main activity. The following discussion describes three aspects: first, marriage and introduction to terrorism and their support for jihad; second, wive role for income-generating; third, support for jihad.

\section{Marriage and the Introduction to Religious Radicalisation}

As mentioned earlier, marriage and family are among the key factors that support religious radicalisation. Previous literature shows women in radical groups are expected to play a domestic role while practicing radical values to purify Islam, such as wearing a chador/full face-covering veil and taking a role for jihadists' regeneration. This section discusses the extent to which the informants' marriage served as an instrument of radicalisation, the extent to which the participants and their families practiced radical values in their daily life.

Despite the expectation that radical groups will try to follow Aisha, the youngest wife of the prophet Muhammad who married him when she was very young, the marriage experience among the wives of the terrorists varies considerably. In general, they had less agency to decide their husband's candidate but the proposal was normal, they were introduced to a man, spent time having intensive interaction with him, and then received and accepted a marriage proposal. Generally, they did not understand jihad and only learned it after their husbands were arrested and sentenced. Some adapted radical practice (wearing a big scarf (chador/full face-covering veil) because of their husband's request during their marriage and some after their husband were arrested 
Ami married her husband without being introduced in the first place. She didn't know her husband's personality and background. Her husband proposed marriage through his brother as an intermediary after only meeting her for a second or third time. She had a boyfriend but she accepted him because of the tradition that one does not reject a man who makes a serious marriage proposal. However, she does not consider it a forced marriage because she accepted it voluntarily (Ami, Personal Communication, August 8, 2016). Ami wore a big scarf (chador/full face-covering veil) when she lived in Malaysia. When she moved to Indonesia, she did not wear it any longer because she felt old and she did not feel comfortable (for health reasons) wearing it. She felt that she has insufficient knowledge about Islam, and that is why she does not teach religion to her children.

Anti (Personal Communication, August 25, 2016) reported that she was 19 years old when she met with the man that is now her husband. She met several times and then agreed to marry. She was an active member of a youth organisation at the residential community for organising activities such as sport, music, events, for the celebration of independence day called Karang Taruna. She actively participated in volleyball, and karawitan (a Javanese musical instrument). When she met her husband, she did not wear hijab as a female Muslim cloth, and only wore pants and casual clothing. She decided to wear hijab (veil) in 1990 because what she understood is that wearing hijab is a must. However, previously wearing a hijab was not famous in her generation.

Lita held the principle that it is forbidden to date and have a close relationship with a man without marriage. She met her husband through a social media site, and a month after the proposal they were married. They had joined a similar religious group discussion in Bekasi. It was not a forced marriage but it was based solely on religious belief.

Some participants (Rani, Dita) experienced an arrangement that was somewhere between voluntary and forced marriage because they met their husband and decided to get married based on the opinions and influence of others without having had a natural interaction as a couple. Rani (Personal Communication, August 31, 2016) stated that she was introduced to her husband only by a photograph by an ustadz (religious teacher), one that would later become involved in the JW Marriot bomb. She trusted the ustadz to choose a pious man for her and she decided to marry her husband based on his piety and religious knowledge. Dita (Personal Communication, August 31, 2016) reported that she married her husband due to family relations, wherein her mother-in-law had a connection with her father. Her father asked her to marry him because he is a policeman and he has good social status and has a stable income.

Nana married soon after graduating from senior high school after her friend had introduced her to her now-husband. Initially, her parents offered her husband her older sister instead but her husband rejected this offer and her parents accepted this decision because they did not want their daughter dating before marriage. The participant believed that a good woman would be married to a good man and therefore she married her husband without knowing his occupation and without having any conversation before their marriage. She spoke to her husband on their wedding day as they walked down the aisle and she knew that he worked as a private teacher and was still studying at university. However, she realised that her husband often met her before their wedding.

Nana was actively engaged in the religious gatherings of Persatuan Islam (PERSIS) and attended a Muhammadiyah school as well as some religious gatherings by famous religious teachers when she was a student in senior high school. She felt that religious teachings in Muhammadiyah groups were more appropriate and satisfied her needs better than religious teachings from traditional groups (Nahdlatul Ulama). She has been married for 16 years, and she understands that her husband was an introvert. Her husband kept his activities relating to religious study a secret. When did she ask her husband, where he went? He only responded shortly, I went to pengajian in Cileunyi (Bandung). She thought that her husband gave more priority to his pengajian activities than to their family affairs and they often argued about her husband's activities. Her husband used to forbid her to intervene in his business. However, she followed his husband's request to wear female Muslimah clothing (and not wear trousers, which for men), and not put on lipstick or other make-up for her appearance. 
Rani graduated from junior high school and continued her education at a pesantren for four years. She has been wearing jilbab (non-face-covering veil) for a long time, as she learned it at her pesantren, but wearing the niqab (face-covering veil) was due to her husband's request, especially when she went outside. However, she only wore jilbab at home. She said that her family is not very religious and she engaged in any religious activities like pengajian conducted by organisations such as Nahdlatul Ulama and Muhammadiyah. Rani was very enthusiastic and committed to religious education and activities but once she got married and had children, she rarely came to the mosque or pengajian. She had been busy raising her children. Her husband often went to ordinary male religious studies like the ones held in the morning (pengajian subuh), which according to her, is just to learn religion as other Muslims do. However, she and her husband used to attend a mass religious study gathering at Istiqlal, the biggest mosque in Indonesia. Her husband's economic activity was renting cars and it led to him being sentenced for his involvement in the JW Marriot bombing.

During the early period of her husband's arrest, Nana did not wear a big scarf (chador/full facecovering veil), while other wives of perpetrators wearing it already. She began wearing it when her husband was imprisoned to adapt to her husband's status. She knows how to cover her body properly based on Islamic teaching, which is meant to avoid transparency and very flashy clothes that may attract male attention and arouse libido. She understands that wearing a chador is not an obligation as it could hide a smile, and she learned from her parent and the hadith (in some of the books that belong to her father) that a smile is a kind of alms (sedekah). Additionally, the Holy Qur'an asks to uncover the face and palm.

\section{Wives' Role for Income Generating}

Some wives of the perpetrators and terrorists were economically independent although their highest-level education is senior high school. However, Anti who only graduated from primary school and has four children supports her first daughter in her wish to continue her education until she received a Master's degree. Her second child has just graduated from her undergraduate degree (Anti, Personal Communication, August 25, 2016). In general, Anti plays a significant role in terms of managing the family income because her husband never provided income for her family. As a seller, she earns her own money while her husband has a separate income. Her husband graduated with his teaching degree but he decided to marry and work in non-permanent jobs, such as construction or transportation as ojek (driver for motorcycle taxi) until finally, they run a business as a vegetable seller.

In their daily life, four participants reported that their husband is just an ordinary man. Anti, mentioned that her husband is a very quiet and passive man. She and Her husband worked together in the market as sellers. They worked from early morning until early afternoon and earned an average of IDR 300,000 - 400, 000 daily. Their economic situation was good enough that they could afford domestic workers to help with domestic tasks. She mentioned that she had never raised her children herself because she had maids to help her. Her husband was also helpful and he helped clean the house, though he never helped with the cooking. She was very shocked to know that her husband had been convicted as a terrorist. As the wife, she only knew that her husband was arrested for being a terrorist and was sent to jail because he saved his friend's property. When the police arrested him, he submitted right away and did not oppose them. Anti does not wear hijab at home when she meets her female neighbour. She did not study at a pesantren, but she did occasionally go to the mosque, learning about basic Islamic knowledge like figh (Islamic jurisprudence), tajwid (how to read the holy Qur'an properly) when she was a child.

The majority of participants were generally a housewife. Some had the experience of earning money for a secondary income, but they did not continue due to various reasons. Two participants (Dita and Lita) graduated from senior high school and they used to work outside the home to earn money in addition to their routine activities as wives and mothers. Lita worked as an administrative staff in a Muhammadiyah school. Her husband wanted her to focus on family but when she asked her husband to contribute some money for her brother's education her husband let her work. However, she eventually resigned when her husband was sentenced as a terrorist because she knew that her boss 
did not like her. Rani ran a small business producing soymilk and selling them to stores when her husband was in jail. She used to live with her sister in West Java and she then moved to Cibubur and live with her father and mother-in-law because they were sick. Ever since she stopped looking after her small business and she now economically relies on her husband's family.

Wives' Support on Jihad

Most of the wives mentioned that they did not know of their husband's activities in the terrorist groups. However, some participants stated that they moderately support radical acts such as jihad against the enemy, or jihad in the right place.

Ami did not know that her husband went to Afghanistan for three years, he left for Afghanistan just three months after their marriage. She had a very hard life because three years later when she was pregnant with her first child, her husband came back and asked her to go with him to Malaysia. She did not know of her husband's involvement in terrorism. They lived in Malaysia and had six children there. Then, in 2001 her husband was arrested and sentenced in Malaysia because he was found to be a member of the KMM (Kelompok Militan Malaysia/Militant group of Malaysia). She believes her husband was arrested without court process. According to her, her husband was a trader and he joined a religious study group (kelompok pengajian) but she had believed that the activities were quite ordinary. She did not feel that her husband's activities were inclusive.

Ami knew some wives of perpetrators of terrorism, but she mentioned that it was not a very close friendship. They participated in similar women's religious study groups but all wives were busy with their activities. She mentioned:"... during pengajian we learned about how to manage the family, not about jihad." (Ami, Personal Communication, August 8, 2016). Only very few of them still maintain contact, but she would occasionally text her friend. Her first and second children went to JI primary school (Lukmanul Hakim) in Malaysia, but they continued to non-JI secondary school. Other children went to ordinary schools in Indonesia. When her husband was sentenced in Malaysia, she returned to Indonesia in 2001 with the help of the Indonesian embassy in Malaysia (KBRI). Her husband returned to Malaysia and was deported to Indonesia 5 years later.

Ami emphasised to her children to keep conducting their daily prayers (five times a day and other recommended prayers). None of her seven children are married to a jihadi. She expects her children not to be involved in acts of the bombing. She said, "even only for thinking... I hope they will not... There is a time when we must join jihad.." (Ami, Personal Communication, August 8, 2016). The time is at the period of independence day when Islam and Muslims are oppressed.

Anti was similarly unaware of her husband's involvement in extremist groups. When Anti was asked about jihad she responded, "I don't know such things... (saya nggak tahu yang gitu-gitu...). I only attended regular pengajian (religious studies)" (Ami, Personal Communication, August 25, 2016). She did not know that her husband had joined a radical group, and she was very angry when she discovered that her husband was involved in a radical act. However, she supported her husband while he was in jail, and still thinks that the radical group took advantage of her husband's character.

My husband is very humble and had never behaved extremely. I was very angry to know this situation, and now I ban him to go and meet his friend. This has made us suffer and felt sorrow. Especially for our children, they will be judged negatively. However, we are lucky because our neighbour, family, and friends support us and they have never judged us, we are safe and our house is safe (Anti, Personal Communication, August 25, 2016).

On the other hand, Rani agreed that to participate in jihad means to have self-control. Similarly, she mentioned that to participate in a war means to fight the enemy but not to participate in bombings. Likewise, she is reluctant if her children were to take part in terrorism. She does not blame her husband for his case and tries to understand his situation, therefore, she keeps their marriage. She visited her husband in prison, and when he was free from prison, her mother in law, brother in law and she warned him not to make similar mistakes of being involved in terrorism. 
Rani attended religious studies and listened to religious lecturers affiliated with radical groups. The topics she enjoyed were mostly about children's education. So, she did not enjoy lectures given by Imam Samudra and considered him very extreme and radical. She does not expect her children to follow her husband's deeds. She said," I am not supportive of bombings in our peaceful country, Indonesia. It is useless, and I don't think Allah will accept that kind of jihad." When she was asked about a recent bombing case in Jalan Thamrin, she considered the perpetrator's motive is to gain fame (Rani, Personal Communication, August 31, 2016).

However, Rani would allow her children to be involved in jihad if Indonesia were attacked by enemies, just like during Indonesia's historical period of struggle for independence. She believes there is a time when Muslims must be involved in jihad, which is when we are oppressed. She said:

That's okay, defending the homeland. Muslims must have that kind of competence. If we don't have it, later on, the enemy may attack our country, it has occurred in Yugoslavia, Bosnia. When Muslims are weak, we will be attacked (Rani, Personal Communication, August 31, 2016).

Rani wears a big scarf and seems more familiar with religious radicalisation; she mentioned that her teacher was a convicted terrorist. The court believed her teacher was the one directly involved in the Ritz Carlton and JW Marriot bombings. In addition, it is believed that her husband hid and protected those who were involved in this act. Her husband rented a house to allow those involved in the crime to stay and thus escape the police. Her husband was initially sentenced to ten years of prison for hiding wanted criminals. She disagrees with the use of bombs for jihad, because she thinks that the biggest sacrifice in jihad is protecting oneself from hawa nafsu (negative ambition) and involving oneself in a war against the enemy. However, she does not reject her husband's act completely but she does not accept it explicitly as well.

We cannot judge that he was entirely wrong because we don't know exactly what was wrong? I chose not to divorce him because I am not a woman who keeps him when he is happy and leaves him when he is in sorrow (Rani, Personal Communication, August 31, 2016).

Rani does not participate actively in the religious study because she is focusing on her role as a housewife. Her husband has a more intense attitude toward learning Islam from religious teachings and he has a better knowledge of Islamic sources written in Arabic although he graduated from a vocational school. She does not know if her husband was an active participant in Islamic studies before their marriage.

All her family members, her mother-in-law and her brother-in-law, encouraged her to convince her husband to leave all activities related to terrorist acts. She does not want her husband and her family to be involved in a similar mistake and be punished as terrorists. She obeys her husband's wish that she wears a chador because she believes that covering her face is a good thing. However, she does not want her family to experience the same situation as her husband. She said that if her husband engaged in jihad it should only be in the right place, such as Palestine or Afghanistan (Rani, Personal Communication, August 31, 2016).

Similarly, the wife of the policeman (Dita) that was sentenced as a member of a terrorist network reported that her husband was responsible for his gun. She did not know that her husband was involved in gun trading and that he sold guns to terrorist groups.

I was frequently angry and warned my husband to be careful and professional about his profession. I realised that my husband was challenged with many temptations because of his position as a police officer. He never told me about his dangerous activities. We were just attending an invitation to a party (kondangan), he looked very anxious... He told me that his friend was caught by the police...the Densus (the police's counterterrorism special detachment). I asked him what is Densus, was because I don't know anything about it. I was so stupid (Dita, Personal Communication, August 31, 2016).

Dita did not know about her husband's activities and she did not know anything about jihad, hijrah (migration), or any other words related to radical group terminology. 
If I were really a member of a terrorist group and I know my husband's activities well, I would not probably be ready to be interviewed. I would worry if I expose any secret and made a mistake during the interview. I did meet some terrorists' wives when my husband was in prison. They brought many things during the visit. I don't know where the money came from. I did not bring anything as a gift for my husband as I did not have money at all. I just came and brought myself to meet my husband (Dita, Personal Communication, August 31, 2016).

However, she supports jihad in Gaza or Palestine and will allow her children to join the real jihad in conflict areas involving Muslims. She has four children: her firstborn, second, and fourth are girls, and her third is a boy. However, she faces the same problems that other mothers and wives have, she has difficulty educating her daughters because they play with gadgets and are not very easy to control. She teaches her children religion and daily ritual practices, such as how to pray and recite the Holy Qur'an.

As the wife of a convicted terrorist, Dita thinks that her husband's action was simply a mistake and that his friend took advantage of his character. In the interview, she stated:

He made a mistake because he did not tell me about his activities. I thought if his friend told him the truth, who bought the gun from him, he would never give the gun to him. His friend lied to him; he told him that the gun was sold to another police (Dita, Personal Communication, August 31, 2016).

Lita is the wife of a terrorist charged with hiding information about the leader of a radical group wanted by the police. They often met in a religious study, and her husband knew the terrorist's family well and he did not tell the police that he knew where the perpetrator was. He was thus convicted of hiding and ignoring information related to security and terror acts. Lita believes that it was unjust for the police to arrest her husband. She cannot accept the police seizing her husband away from her. She tried to convince the police to let her husband go.

We just welcomed a guest, provided him with a cup of tea... it does not mean that we hide information. We did not know the guest was a person wanted by the police. It is said that the information about the guest being a wanted person has been published on television, but we did not watch TV intensively (Lita, Personal Communication, September 2, 2016).

In general, Lita disagrees with resorting to violence to convert people. Similarly, she disagrees with the bombing in non-conflict areas as she understands that the victims could be believers working at the targeted site, or mere passers-by. However, she believes, as her husband does, that bombing for jihad is acceptable in conflict areas such as Palestine. Jihad, according to her, should not be conducted extremely even towards non-believers if they act fairly toward Muslims and do not disturb their activities.

The network between convicted terrorists is quite strong as they provide one another with jobs when they get out of prison. However, Lita does not trust that other terrorists are concerned with justice and are not only thinking about their self-interest. Lita's husband was occasionally challenged by conflict. She reported that her husband had been treated like a servant and made to work 24 hours nonstop. Similarly, she is not trusting ISIS and she declared that she opposes ISIS even though those opposing ISIS are labelled as government sympathisers and infidels by other terrorists.

Nana understands her husband's dream to be involved in jihad in conflict-ridden countries such as Palestina. Muslims in this country deserve a safe life, and as such, they need to be defended. She tolerates her husband's activities carrying out several bombing tests in the jungle because it does not affect other people. However, she rejects jihad and bombing in Indonesia.

I am happy to say please go for jihad in Gaza Palestina but not in Indonesia. People in Indonesia are at peace, they do not invite war. If they call for war, we respond to them but we live here in Indonesia, a peaceful country. God creates warring and peaceful countries. When we live in a peaceful country, let's be peaceful, don't create conflicts (Nana, Personal Communication, September 22, 2016). 
She regrets the Bali bombings because they injured innocent people.

Australians, Americans came to Indonesia for holiday, and then there was news that the military was coming so, the bombings were executed. However, the victims were civilians and the soldiers were safe. I think the bombings were misplaced, it should be in Palestina (Nana, Personal Communication, September 22, 2016).

Nana was dissatisfied that her husband was arrested and sentenced to 6 years because she knew many others committed greater acts of terror than her husband did, yet they were safe. Her husband was only testing his self-made bombing and it did not hurt anyone. However, in the end, she was grateful that her husband changed his mind about jihad. Her husband thought that jihad required his life and he was willing to die. He changed his mind that jihad is the struggle to care for one's wife, children, and family. Many religious teachers do not educate their wives and children properly and they behave unproperly. She believes when they die (during the judgment day), the first thing to become their responsibility is their family. She does not want her children to make the similar mistake her husband committed, she worries about her children's trauma so she tries to prevent her children from doing such things.

\section{Passive Supporters and Rescuing the Family from Radical's Engagement: Women's Agency as Wives and Mothers}

Female terrorist combatants in Indonesia had just started in 2009 when the Mujahidin Indonesia Timur (MIT) began recruiting and training three women in $i^{\prime} d a d$ or war simulation, on account of their lack of human resources. Even at the time, there were no records of these women being involved in any planned attacks. Literature from 2010 was still questioning the possibility of women participating in terrorism (Saputro, 2010). It was only nearing the end of 2016, given the emergence of IS-affiliated Jamaah Ansharut Daulah (JAD) "brides", that Dian Yulia Novi and Ika Puspitasari, were the first Indonesian women who participated in attempted terrorist attacks. Even so, the two were apprehended before successfully detonating the bombs they brought with them (IPAC, 2017; Qori'ah, 2019).

Despite the growing role of women in radical groups that has been documented in previous findings (Bloom, 2011; Bloom \& Lokmanoglu, 2020; Perešin, 2015; Spencer, 2016; von Knop, 2007); the current study about the wives of deradicalised terrorists did not find enough data to support the claim that participants actively engaged in radicalisation. Based on research data, the wives of deradicalised terrorists tend to participate through their domestic role. For the most part, they did not know of their husband's activities or that they were dangerous from a security perspective. Similarly, they tend to disagree with the use of violence against non-believers in peaceful areas such as Indonesia. Some regretted that they did not know about their husband's activities and blamed their husbands' friends as well as their husband for not discussing the situation with them. Those are all reflected in their agency in response to jihad and terrorism. It is important to note that women's level of involvement may be influenced by women's agency as some studies have focused on women's agency in religious organisations (Burke, 2012; Rinaldo, 2014) and women's agency in radicalisation and deradicalisation (Azca \& Putri, 2021).

The agency of the participants seems to be more appropriate and potential for deradicalisation. Initially, they did not know about their husband's activities relating to jihad. Once they knew, they were more likely to disagree and reject their husband's activities. Their disagreement with their husband, the arguments they had between them, the questions they asked about their husband's activities in pengajian, and their dissatisfaction with their husband being too busy with pengajian activities and ignoring their family, these issues have burdened their husband and have become push factors for terrorists to quit from jihad (Hwang, 2017). However, they do support jihad in conflict areas such as Pakistan, Afghanistan, and Gaza, and they encourage their families to become involved in these conflicts.

Although the six participants married to deradicalised perpetrators blamed their husbands for not informing them about their radical activities, somehow, they still support their husbands by defending 
them and arguing that their husbands had been victimised. They consider their husband was not involved in dangerous actions and the arrest followed the wrong procedure. This is almost similar to the argument of previous research (Maghfur \& Muniroh, 2013) that wives of terrorists believe that the terrorists are not their husbands but those who judge others as terrorists, those who destroy and oppress Islam. Only participant 2 strictly responded, not to be connected to things related to jihad. Others still positively consider jihad and allowing violence in conflict-ridden countries such as Gaza Palestina and Bosnia.

Some actively support their family economically while their husbands were absent as family breadwinners. This confirms Spencer (2016) argument that the role of women in radical groups can be classified into two categories: domestic involvement as a wife and mother, and operational involvement as a skilled woman operative. Women in jihadist groups have been argued to mainly hold the role of earning income to sustain their family (IPAC, 2017) while their spouse engages in jihad, preparing their young to become future jihadists or fighters for a sharia state (Abdul Nasir, 2019; Azca \& Putri, 2021; Bloom, 2011; de Leede, 2018; IPAC, 2017), as well as assisting in logistical and financial exchanges among members (Fitriani and Arif, 2018). However, the participants interviewed in the study did not openly declare their roles. Their daily life does not indicate that they educate their children to continue their father's activities. They allow their children to pursue jihad in Palestina, passively, but they mostly consider terrorist acts in Indonesia (Bali Bombing, JW Marriot bombing) negatively. Only Participant 2 mentioned clearly that she is economically independent. Others rely on their father/mother or brotherin-law, their parent, their family (brother/sister).

The six wives of the deradicalised terrorists are either passive supporters or passive preventers (Azca \& Putri, 2021). They argue that their husband should be freed from being sentenced as a terrorist, but they agree that their husband desired to wage jihad in other countries (Palestine, Bosnia, and others). They have been radicalised to accept violence as an instrument of jihad and have joined a radical group under their husband's membership. Following Silber and Bhatt (2007), the wives of deradicalised terrorists are at the first and second phases of religious radicalisation.

The reality that women's involvement is rather limited may be associated with the old ideology of excluding women from jihad (IPAC, 2017). It is unlikely that the religious conservative audience whom jihadists appeal to among the Muslim community would favour recruiting women to engage in the battlefield. The old jihadists, accordingly, promote the value of roles that women uphold in the private sphere instead. Most jihadists believe that successful jihad relies on the non-military assistance women provide, e.g., as a jihadist's mother, sister, and wife. They depend on women to move jihad forward in both the domestic and public spheres by raising funds for jihadists and preaching the merit that jihad offers to other Muslims in mosques, via print and online publications (Lahoud, 2014).

The wive of deradicalised perpetrators are different from female perpetrators such as Ika Puspitasari and Dian Yulia Novi together with those nine women identified by Bhakti (2016) and the IPAC (2017). Those nine female perpetrators mentioned in report by (Bhakti, 2016; IPAC, 2017) are Putri Munawaroh, Ingrid Wahyu Cahyaningsih, Munfiatun, Rasidah Najwa binti Subari alias Firda, Ruqayah binti Husein Luceno, Deni Carmelita, Nurul Azmy Tibyani, Rosmawati, and Arina Rahmah). Nevertheless, jihadist groups influenced Dian Yulia Novi and Ika Puspitasari directly and influence those nine women through the role of their husbands. Their husband invited them to become involved in jihad, and they were directly involved in various contributions to support their husbands.

Women who were convicted by the court as a partner in jihad have very strong and have the agency to be involved in religious radicalisation. For example, based on the court rulings, Ika Puspitasari and Dian Yulia Novi are voluntarily involved in jihad and terrorism, and the first Indonesian women who participated in attempted terrorist attacks who declared it openly (IPAC, 2017; Qori'ah, 2019). Similarly, the nine women convicted of terrorism engaged in jihad voluntarily by doing things such as receiving a terrorist guest and allowing terrorists to stay in their home for two months, and as a result, she was sentenced to three years of prison, and she then remarried with a convicted terrorist; hiding people who perpetrated criminal acts of terrorism; and concealing information relating to perpetrators of terrorism; deciding to marry to a man involved in a radical organisation, of which she knew for a fact; 
giving donations (Bhakti, 2016; IPAC, 2017). These kinds of activities are only made possible with a significant level of agency, and bravery for them to engage in such terrorist-related activities. One of the convicted terrorists, Munawaroh even sacrificed her leg to defend their guest, Noordin M. Top, who was the person most wanted by the police.

By contrast, the six participants disagree with their husband's involvement in pengajian and ignore their family, they ask their children not to follow their father's activities, they regret the bombings in Indonesia and consider the actions were useless, God will not accept it and will not consider it as jihad. Their extended family persuaded the participants to ask their husbands to leave their group and their previous activities. The wives did not intensively attend pengajian relating to their husband's activities. They know other wives of terrorism perpetrators but do not have a very close friendship. Some still exchange texts occasionally. They are not part of state-building organisations which have officially declared the establishment of their states (caliphates).

\section{Conclusion}

To sum up women's involvement, in the case of Indonesia, wives of terrorists in the religious organisation are rather varied (active supporter, passive supporter, active prevent, passive prevent). Previous studies have identified factors such as ideology and paradigm (Lahoud, 2014), level of agency (Azca \& Putri, 2021; Burke, 2012; Rinaldo, 2014), and the type of organisation they are affiliated to (Khelghat-Doost, 2019).

Wives whose husbands have been deradicalised in the current study only had very limited involvement, they even stated ignorance of their husbands' activities in the terrorist groups. Following Silber \& Bhatt (2007), they experienced only the first three stages of religious radicalisation facilitated by their marriage to members of jihadist groups. Their agency is more potentials for her husband and family disengagement from radicalisation as they did not actively engage in radical networks, pengajian, distrust to IS/ISIS, do not obtain significant support economically from the radical group, this confirms previous studies about factors for terrorist dissolution (Altier et al., 2014; Cherney, Putra, Putera, Erikha, \& Magrie, 2021; Hwang, 2017; Syafiq, 2019).

The study has its limitations as all the husbands of the participants successfully interviewed in the study merely held mid-level positions in their radical organisations, and also limited because it does not cover depth data on their role in disengagement of their husband.

\section{References}

Abdul Nasir, A. (2019). Women in Terrorism: Evolution from Jemaah Islamiyah to Islamic State in Indonesia and Malaysia. Counter Terrorist Trends and Analyses, 11(2), 19-23. Retrieved from www.rsis.edu.sg

Agara, T. (2015). Gendering Terrorism: Women, Gender, Terrorism and Suicide Bombers. International Journal of Humanities and Social Science, 6(1), 115-125.

Ali, S. S., \& Rehman, J. (2005). The concept of Jihad in Islamic international law. Journal of Conflict and Security Law, 10(3), 321-343. https://doi.org/10.1093/jcsl/kri017

Altier, M. B., Thoroughgood, C. N., \& Horgan, J. G. (2014). Turning away from terrorism: Lessons from psychology, sociology, and criminology. Journal of Peace Research, 51(5), 647-661. https://doi.org/10.1177/0022343314535946

Aly, A., \& Striegher, J. L. (2012). Examining the role of religion in radicalization to violent Islamist extremism. Studies in Conflict and Terrorism, 35(12), 849-862. https://doi.org/10.1080/1057610X.2012.720243

Andrews, S. (2020). Prevent Tragedies : A case study in female-targeted strategic communications in the United Kingdom' s Prevent counter- terrorism policy Fall 2020 Prevent Tragedies: A case study in female-targeted strategic communications in the United Kingdom's Preve. (September).

Aoláin, F. N. (2013). Situating women in counterterrorism discourses: Undulating masculinities and luminal femininities. Boston University Law Review, 93(3), 1085-1122.

Azca, M. N., \& Putri, R. D. (2021). PEREMPUAN DAN PERAN REGENERASI DALAM LINGKARAN EKSTREMISME KEKERASAN: Narasi dari Indonesia Timur. 15(1).

Bélanger, J. J., Robbins, B. G., Muhammad, H., Moyano, M., Nisa, C. F., Schumpe, B. M., \& Blaya-Burgo, M. (2020). Supporting political violence: The role of ideological passion and social network. Group Processes and Intergroup Relations, 23(8), 1187-1203. https://doi.org/10.1177/1368430220933954 
Berko, A., \& Erez, E. (2007). Gender, Palestinian women, and terrorism: Women's liberation or oppression? Studies in Conflict and Terrorism, 30(6), 493-519. https://doi.org/10.1080/10576100701329550

Bhakti, M. A. (2016, February 8). Perempuan dan Terorisme. Retrieved from https://www.radicalismstudies.org/96/2016/02/perempuan-dan-terorisme.html

Bloom, M. (2011). Women and Terrorism: Bombshell. Philadelphia: University of Pennsylvania. Retrieved from https://www.upenn.edu/pennpress/book/14946.html

Bloom, M., \& Lokmanoglu, A. (2020). From Pawn to Knights: The Changing Role of Women's Agency in Terrorism? In Studies in Conflict and Terrorism (Vol. 0). Routledge. https://doi.org/10.1080/1057610X.2020.1759263

Burke, K. (2012). Women's Agency in Gender-Traditional Religions. Sociology Compass, 6(2), 122-133.

Cherney, A., Putra, I. E., Putera, V. S., Erikha, F., \& Magrie, M. F. (2021). The push and pull of radicalization and extremist disengagement: The application of criminological theory to Indonesian and Australian cases of radicalization. Journal of Criminology, 54(4), 407-424. https://doi.org/10.1177/26338076211034893

Cox, M. (2009). Social Capital and Peace-Building. New York: Routledge.

de Leede, S. (2018). Women in Jihad: A Historical Perspective. Terrorism and Counter-Terrorism Studies, (September). https://doi.org/10.19165/2018.2.06

Doosje, B., Moghaddam, F. M., Kruglanski, A. W., de Wolf, A., Mann, L., \& Feddes, A. R. (2016). Terrorism, radicalization and de-radicalization. Current Opinion in Psychology, 11, 79-84. https://doi.org/10.1016/j.copsyc.2016.06.008

Fenton, A. J. (2014). Change and continuity in Indonesian Islamist ideology and terrorist strategies. Al-Jami'ah, 52(1), 1-24. https://doi.org/10.14421/ajis.2014.521.1-24

Fikriyati, U. N. (2015). Perempuan Dan Deradikalisasi: Peran Para Istri Mantan Narapidana Terorisme Dalam Proses Deradikalisasi. Jurnal Sosiiologi Reflektif, 9(2), 1-29.

Hwang, J. C. (2017). The disengagement of Indonesian Jihadists: Understanding the pathways. Terrorism and Political Violence, 29(2), 277-295. https://doi.org/10.1080/09546553.2015.1034855

IPAC. (2017). Mothers to Bombers: The Evolution of Indonesian Women Extremists. (35), 27. Retrieved from http://file.understandingconflict.org/file/2017/01/IPAC_Report_35.pdf

Ismail, N. H. (2007). Al Qaeda's Southeast Asia, Jamaah Islamiyah and Regional Terrorism: Kinship and Family Links. The Asia-Pacific Journal , 5(1), 1-10. Retrieved from https://apjjf.org/-Noor_HudaIsmail/2318/article.pdf

Ismail, N. H. (2020). The unique legacy of the "Islamic State" in Indonesia. Counter Terrorist Trends and Analyse, 12(2), 17-20.

Jones, D. A., \& Dawson, L. L. (2021). Re-examining the explanations of convert radicalization in Salafi-Jihadist terrorism with evidence from Canada. Behavioral Sciences of Terrorism and Political Aggression, 0(0), 1-28. https://doi.org/10.1080/19434472.2021.1919911

Kaakinen, M., Räsänen, P., Näsi, M., Minkkinen, J., Keipi, T., \& Oksanen, A. (2018). Social capital and online hate production: A four country survey. Crime, Law and Social Change, 69(1), 25-39. https://doi.org/10.1007/s10611017-9764-5

Khelghat-Doost, H. (2019). The strategic logic of women in Jihadi organizations. Studies in Conflict and Terrorism, 42(10), 853-877. https://doi.org/10.1080/1057610X.2018.1430656

Lahoud, N. (2014). The neglected sex: The Jihadis' exclusion of women from Jihad. Terrorism and Political Violence, 26(5), 780-802. https://doi.org/10.1080/09546553.2013.772511

Lynch, M. (2010). Islam divided between salafi-jihad and the Ikhwan. Studies in Conflict and Terrorism, 33(6), 467487. https://doi.org/10.1080/10576101003752622

Maghfur, M., \& Muniroh, S. (2013). Perempuan Di Balik Teroris. Analisa, 20(2), 181-195.

Malthaner, S. (2014). Contextualizing Radicalization: The Emergence of the "Sauerland-Group" from Radical Networks and the Salafist Movement. Studies in Conflict and Terrorism, 37(8), 638-653. https://doi.org/10.1080/1057610X.2014.921767

Milla, M. N., Faturochman, \& Ancok, D. (2013). The impact of leader-follower interactions on the radicalization of terrorists: A case study of the Bali bombers. Asian Journal of Social Psychology, 16(2), 92-100. https://doi.org/10.1111/ajsp.12007

Noor, M. (1985). The Doctrine of Jihad: An Introduction. 3(2), 381-397. Retrieved from https://www.jstor.org/stable/pdf/1051182.pdf?casa_token=BeUjPbs6s4YAAAAA:0ztkWrzREZR0iDQP6pc4 LIXvNeAAJxeZFaJELYTNhOh1IT6xYTUHiDZDfEKUSrtERPDwN3B_1fTPbPZjZ80Tn33P5WPnv3jK1Cvoy p5Mz6IaU6oFBx-gg

O'Rourke, L. A. (2009). What's special about female suicide terrorism? Security Studies, 18(4), 681-718. https://doi.org/10.1080/09636410903369084

Osman, S. (2010). Jemaah Islamiyah: Of Kin and Kind. Journal of Current Southeast Asian Affairs, 29(2), 157-175. 
https://doi.org/10.1177/186810341002900205

Perešin, A. (2015). Fatal Attraction: Western Muslims and ISIS. Perspectives on Terrorism, 9(3), 21-38.

Putra, D. A., \& Sumaryani, N. M. (2021). Terrorism and Jihad in Islamic Perspective. International Journal of Islamic Khazanah, 11(2), 78-89. https://doi.org/10.15575/ijik.v11i2.12483

Qori'ah, S. M. (2019). Keterlibatan Perempuan dalam Aksi Terorisme di Indonesia. Sawwa: Jurnal Studi Gender, 14(1), 31. https://doi.org/10.21580/sa.v14i1.2967

Rinaldo, R. (2014). Pious and Critical: Muslim Women Activists and the Question of Agency. Gender and Society, 28(6), 824-846. https://doi.org/10.1177/0891243214549352

Riyani, I. (2021). Islam, Women's Sexuality and Patriarchy in Indonesia: Silent Desire. OXON: Routledge.

Rufaedah, A., \& Putra, I. E. (2018). Coping with stigma and social exclusion of terror-convicts' wives in Indonesia: An interpretative phenomenological analysis. Qualitative Report, 23(6), 1334-1346. https://doi.org/10.46743/2160-3715/2018.3118

Saputro, M. E. (2010). Probabilitas Teroris Perempuan di Indonesia. Jurnal Ilmu Sosial Dan Ilmu Politik, 14(2), 211228. https://doi.org/10.22146/jsp.10937

Satterthwaite, M. L., \& Huckerby, J. C. (Eds.). (2013). Gender , National Security, and. London Newyork: Routledge. Retrieved from file://D:/Downloads/10.4324_9780203081396_previewpdf.pdf

Sela-Shayovitz, R., \& Dayan, H. (2021). Female Palestinian Terrorists: The Role of the Intifada Period and the Terrorism Context. Studies in Conflict and Terrorism, 44(8), 668-685. https://doi.org/10.1080/1057610X.2019.1575027

Shamaileh, A. (2017). Trust and Terror Social Capital and the Use of Terrorism as a Tool of Resistance. New York: Routledge. Retrieved from https:/www.mendeley.com/catalogue/6ea8cc19-812f-3dc6-81453f19165ef4b6/?utm_source=desktop

Silber, M. D., \& Bhatt, A. (2007). Radicalization in the west: The homegrown threat. 1-90. https://doi.org/10.1177/036354659001800501

Sjoberg, L., \& Gentry, C. E. (2011). Women, Gende, and Terrorism. Athen \& London: The University of Georgia Press. Retrieved from http://library.lol/main/B226896C3482663EDF0B1A9C3643F2BA

Sjödin, C. (2004). The power of identity and the end of patriarchy: Reflections on Manuel Castells' book on the network society. International Forum of Psychoanalysis, 13(4), 264-274. https://doi.org/10.1080/08037060410000678

Spencer, A. N. (2016). The hidden face of terrorism: An analysis of the women in Islamic State. Journal of Strategic Security, 9(3), 74-98. https://doi.org/10.5038/1944-0472.9.3.1549

Syafiq, M. (2019). Deradicalisation and Disengagement from Terrorism and Threat to Identity: An Analysis of Former Jihadist Prisoners' Accounts. Psychology and Developing Societies, 31(2), 227-251. https://doi.org/10.1177/0971333619863169

von Knop, K. (2007). The female Jihad: Al Qaeda's women. Studies in Conflict and Terrorism, 30(5), $397-414$. https://doi.org/10.1080/10576100701258585

Wiktorowicz, Q. (2006). Anatomy of the Salafi movement. Studies in Conflict and Terrorism, 29(3), $207-239$. https://doi.org/10.1080/10576100500497004

Winter, D. A., \& Muhanna-Matar, A. (2020). Cycles of Construing in Radicalization and Deradicalization: A Study of Salafist Muslims. Journal of Constructivist Psychology, 33(1), 58-88. https://doi.org/10.1080/10720537.2018.1536904

(C) 2021 by the authors. Submitted for possible open access publication under the terms and conditions of the Creative Commons Attribution (CC BY SA) license (https://creativecommons.org/licenses/by-sa/3.0/). 
This page is intentionally left blank 